\title{
Amphidinolides and Its Related Macrolides from Marine Dinoflagellates
}

\author{
Jun'ichi Kobayashi
}

Received: February 29, 2008 / Accepted: April 25, 2008

(C) Japan Antibiotics Research Association

\begin{abstract}
This review covers the recent results described in our publications on several new cytotoxic macrolides isolated from dinoflagellates of the genus Amphidinium in addition to an overview of the isolation, structure elucidation, synthesis, biosynthesis, and bioactivity of a series of cytotoxic macrolides, named amphidinolides, reported so far.
\end{abstract}

1. Introduction

2. Culture of Dinoflagellates Amphidinium sp.

3. Isolation of New Macrolides

3-1. Amphidinolactones A and B

3-2. Iriomoteolides $1 \mathrm{a} \sim 1 \mathrm{c}$ and $3 \mathrm{a}$

3-3. Amphidinolides $B 6$ and $B 7$

4. Synthetic Studies of Amphidinolides

4-1. Amphidinolide $\mathrm{E}$

4-2. Amphidinolide $H$

4-3. Amphidinolide $V$

4-4. Amphidinolide $N$

4-5. Amphidinolides $X$ and $Y$

5. Mechanism of Action of Amphidinolides $B$ and $H$

6. Biosynthetic Studies of Amphidinolides

7. Conclusion

Keywords marine dinoflagellates, Amphidinium sp., macrolides, amphidinolides, stereochemistry, total synthesis

J. Kobayashi: Graduate School of Pharmaceutical Sciences, Hokkaido University, Sapporo 060-0812, Japan,

E-mail: jkobay@pharm.hokudai.ac.jp 


\section{Introduction}

Marine dinoflagellates, a diverse group of unicellular eukaryotes, have been recognized as real producers of marine toxins responsible to fish and algal poisoning, as well as biologically unique organisms due to their taxonomic position and unusual chromosome structure and composition. Marine dinoflagellates have also proved to be one of the most important source of bioactive natural products, which have been investigated worldwide. We have continuously studied structurally intriguing and biologically interesting bioactive macrolides and polyketides from dinoflagellates Amphidinium sp., which are symbionts of Okinawan marine flatworms Amphiscolops sp.

Thirty-four cytotoxic macrolides, designated amphidinolides $\mathrm{A} \sim \mathrm{H}(\mathbf{1} \sim \mathbf{8}), \mathrm{J} \sim \mathrm{S}(\mathbf{9} \sim \mathbf{1 8}), \mathrm{T} 1$ (19), $\mathrm{U} \sim \mathrm{Y}$ (20 24), G2 (25), G3 (26), H2 H5 (27 30), and T2 T5 (31 34), have been isolated from Amphidinium sp. by our group untill 2003, (Fig. 1) [1 6]. Isolation yields and cytotoxicity of the amphidinolides are shown in Table 1. Due to their unique structures and potent cytotoxicity, amphidinolides have been fascinating targets for total synthesis. Total syntheses of amphidinolides A (1), J (9), $\mathrm{K}$ (10), P (15), R (17), T1 (19), T3 T5 (32 34), W (22), $\mathrm{X}(\mathbf{2 3})$, and $\mathrm{Y}(\mathbf{2 4})$ have been achieved so far.

Recently, eleven new macrolides, amphidinolides B4 (35), B5 (36), and C2 (37), amphidinolactones A (38) and $\mathrm{B}(39)$, iriomoteolides $1 \mathrm{a} \sim 1 \mathrm{c}(\mathbf{4 0} \sim \mathbf{4 2})$ and $3 \mathrm{a}(\mathbf{4 3})$, and amphidinolides B6 (45) and B7 (44), (Table 1) have been isolated from five strains (Y-100, Y-71, Y-25, HYA024, and HYA002) of the genus Amphidinium, which were collected at different location in Okinawa. This review covers recent progress on the isolation and structure elucidation of these cytotoxic macrolides as well as the molecular target of amphidinolide $\mathrm{H}(\mathbf{8})$, cloning of the putative polyketide synthase (PKS) gene of amphidinolide biosynthesis, and synthesis of some amphidinolides recently achieved by other groups. This review follows our early reviews published in 1993 [1], 1997 [2], 1999 [3, 4], 2003 [5], 2004 [6], and 2007 [7]. Synthetic works on amphidinolides up to 2000 were reviewed by Chakrabory and Das [8]. Other reviews concerning amphidinolides have been also reported [9 14].

\section{Culture of Dinoflagellates Amphidinium sp.}

Large-scale cultures of the dinoflagellates of the genus Amphidinium have been performed using seawater medium enriched with Provasoli's Erd-Schriber (ES) supplement. Static incubation with illumination in a cycle of 16 hours of light and 8 hours of darkness was carried out for two weeks at $25^{\circ} \mathrm{C}$. The cultures were harvested by removal of the supernatant through suction and then centrifugation to obtain algal cells. Harvested cells were extracted with $\mathrm{MeOH}$ - toluene, and the extracts were subjected to a systematic separation using several chromatographies to yield cytotoxic macrolides [15 26].

\section{Isolation of New Macrolides}

\section{3-1. Amphidinolactones $A$ and $B$}

A new 13-membered macrolide, amphidinolactone A (38), $\mathrm{C}_{20} \mathrm{H}_{30} \mathrm{O}_{4}$, was isolated from a strain (Y-25) of a dinoflagellate Amphidinium sp. [15]. Detailed analyses of the ${ }^{1} \mathrm{H}-{ }^{1} \mathrm{H}$ COSY spectrum of $\mathbf{3 8}$ revealed connectivities of a long carbon chain from $\mathrm{C}-2$ to $\mathrm{C}-20 .{ }^{1} \mathrm{H}$ and ${ }^{13} \mathrm{C}$ chemical shifts of $\mathrm{CH}_{2}-2$ and $\mathrm{CH}-12$ suggested that $\mathrm{C}-12$ was involved in an ester linkage with $\mathrm{C}-1 .{ }^{1} \mathrm{H}-{ }^{1} \mathrm{H}$ couplings of the two disubstituded double bonds at C-5 and C-9 indicated the $Z$ and $E$ geometries, respectively. Geometries of two disubstituted double bonds at C-14 and C-17 were assigned as both $Z$ by NOESY correlations and the carbon chemical shift of $\mathrm{C}-16$, which was a typical value for a methylene carbon between two $Z$ double bonds. Thus, the gross structure of amphidinolactone $\mathrm{A}$ was elucidated to be 38. The relative configurations at C-8, C-11, and C-12 in 38 were deduced from NOESY correlations.

A new 26-membered macrolide, amphidinolactone $\mathrm{B}$ (39), $\mathrm{C}_{32} \mathrm{H}_{54} \mathrm{O}_{8}$, has been isolated from the same dinoflagellate Amphidinium sp. (strain Y-25) as described above [16]. Detailed analyses of the ${ }^{1} \mathrm{H}-{ }^{1} \mathrm{H}$ COSY and TOCSY spectra as well as HMBC correlations indicated connectivities of a long carbon chain from C-2 to C-26. ${ }^{1} \mathrm{H}$ and ${ }^{13} \mathrm{C}$ chemical shifts of $\mathrm{C}-25$ indicated that $\mathrm{C}-25$ was involved in an ester linkage with $\mathrm{C}-1$. The NOESY correlation for $\mathrm{H}-2 / \mathrm{H}-25$ also supported the connectivity of $\mathrm{C}-25$ to $\mathrm{C}-2$. The connectivity of $\mathrm{C}-19$ to $\mathrm{C}-21$ through a remaining keto carbonyl at $\mathrm{C}-20$ was deduced from the molecular formula of $\mathbf{3 9}$ and the NOESY correlation. The presence of a tetrahydrofuran ring was deduced from deuterium-induced shift of oxymethine carbons in the HSQC spectra of 39. The ${ }^{1} \mathrm{H}-{ }^{1} \mathrm{H}$ coupling of the disubstituted double bond at C-7 indicated the $E$ geometry. The $E$ geometry of the double bond at C-13 was suggested from the NOESY correlation and the ${ }^{13} \mathrm{C}$ chemical shift of C-29. Thus, the gross structure of amphidinolactone B was elucidated to be 39. The relative stereochemistry of the tetrahydrofuran ring was deduced from NOESY 


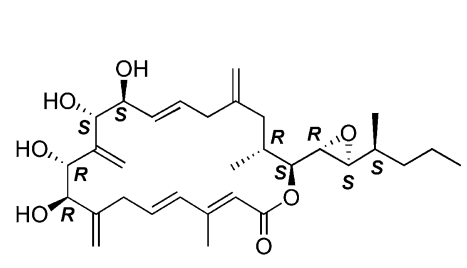

1

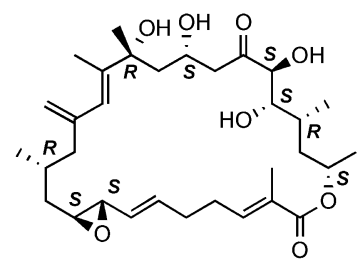

4

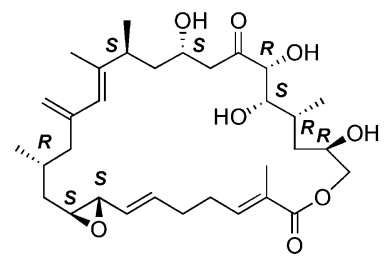

7

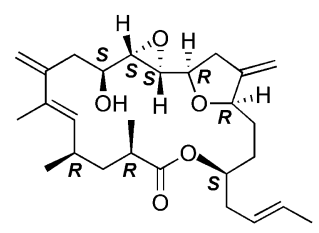

10

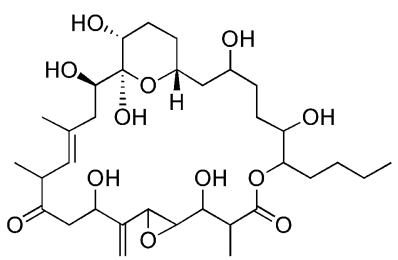

13

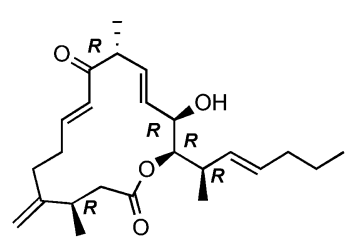

18

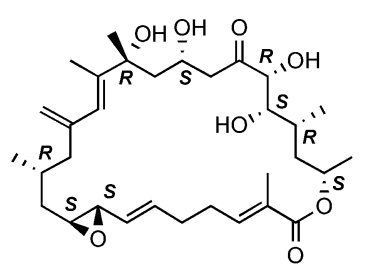

2

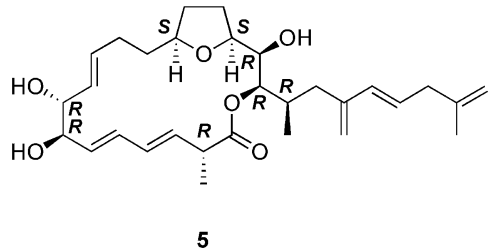

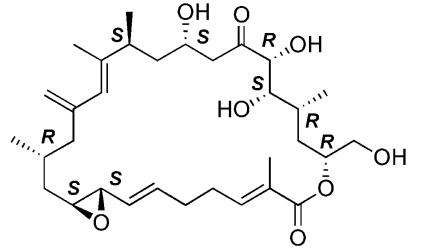

8

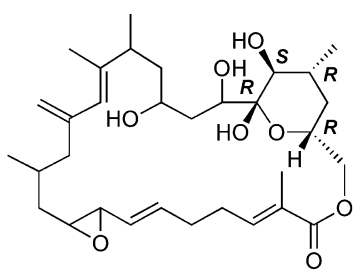

11

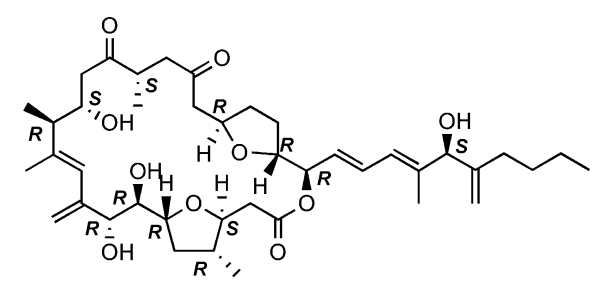

3

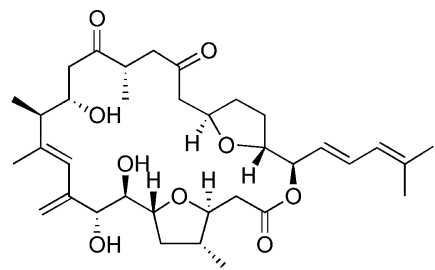

6

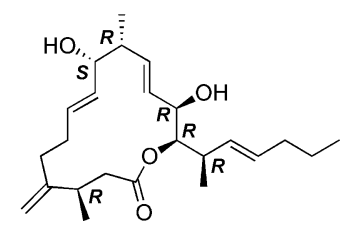

9

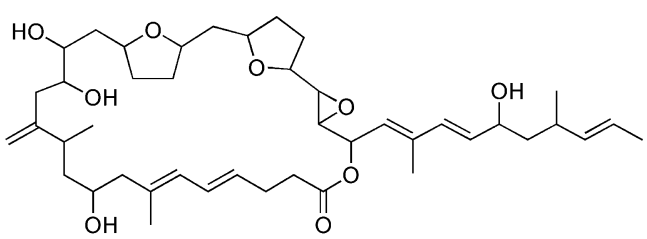

12

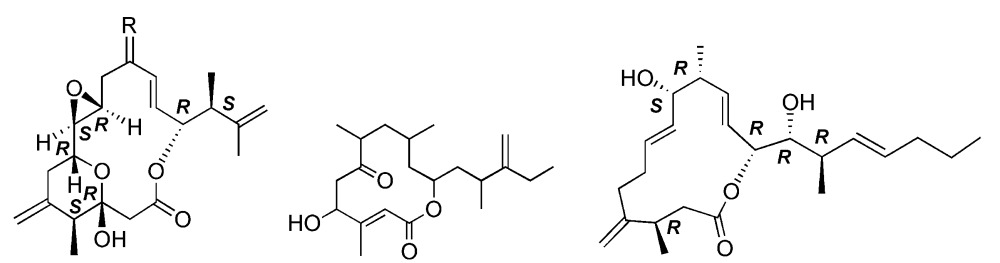

$14 \mathrm{R}=\mathrm{O}$

$15 \mathrm{R}=\mathrm{CH}_{2}$

16

17

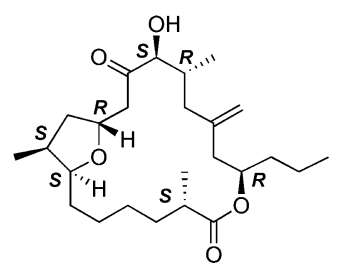

19

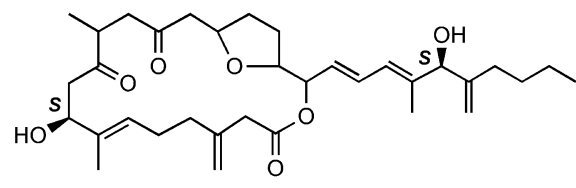

20 
<smiles>C=C(C)/C=C/C/C=C/CC(=C)CC(=O)OC(=O)CCC(=O)CC(=C)CC1OC1C1OC1C</smiles>

21

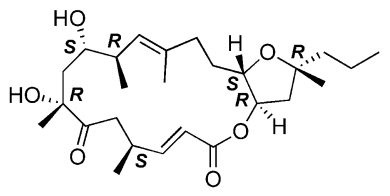

24

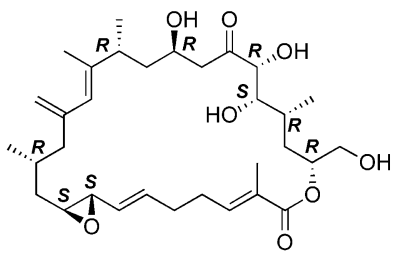

27

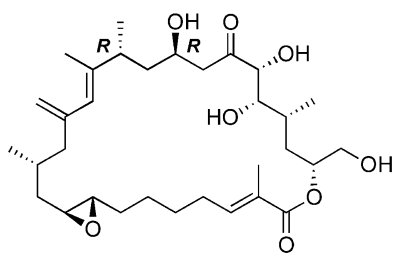

30

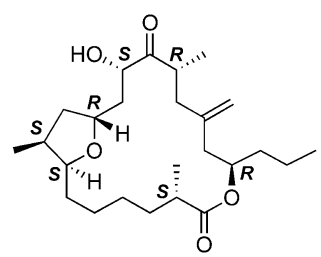

33<smiles>CC/C=C/C(C)=C/[C@H](C)C[C@@H](O)[C@@H]1/C=C/CC[C@@H](C)C(=O)CC[C@@H](C)C(=O)O1</smiles>

22

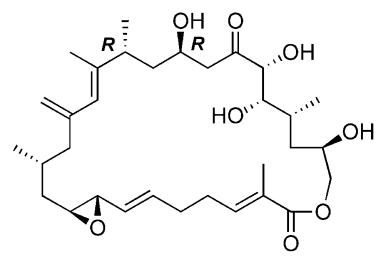

25

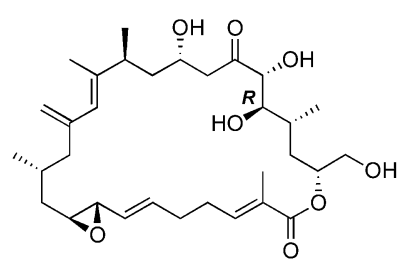

28

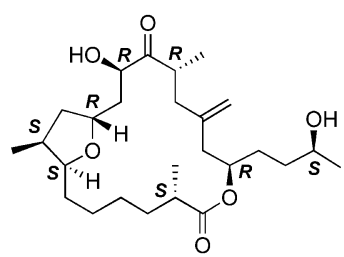

31

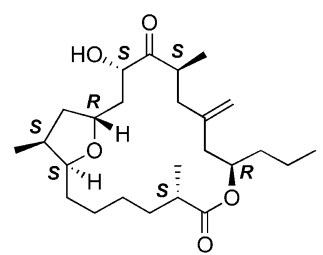

34

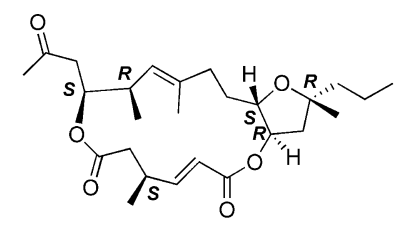

23

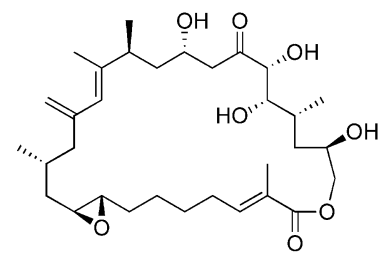

26

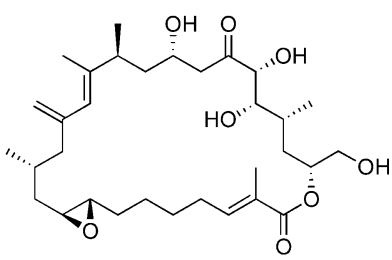

29

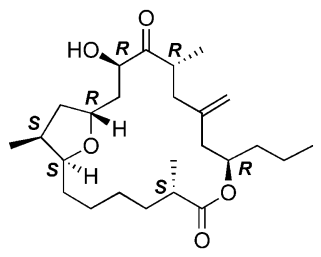

32

Fig. 1 Structures of amphidinolides $A \sim H, J \sim S, T 1, U \sim Y, G 2 \sim G 3, H 2 \sim H 5$, and $T 2 \sim T 5(\mathbf{1} \sim \mathbf{8}, \mathbf{9} \sim \mathbf{1 8}, \mathbf{1 9}, \mathbf{2 0} \sim \mathbf{2 4}, \mathbf{2 5} \sim \mathbf{2 6}$, $\mathbf{2 7} \sim \mathbf{3 0}$, and $\mathbf{3 1} \sim \mathbf{3 4}$, respectively).

correlations, while that of C-2, C-22, C-23, and C-25 was assigned from ${ }^{1} \mathrm{H}-{ }^{1} \mathrm{H}$ couplings and NOESY correlations. Furthermore, considering conformation of the macrocyclic ring, the relative stereochemistries of the $\mathrm{C}-21 \sim \mathrm{C}-25$ and $\mathrm{C}-1 \sim \mathrm{C}-2$ moieties were elucidated.

\section{3-2. Iriomoteolides $1 \mathrm{a} \sim 1 \mathrm{c}$ and $3 \mathrm{a}$}

A potent cytotoxic 20 -membered macrolide, iriomoteolide 1a (40), $\mathrm{C}_{29} \mathrm{H}_{46} \mathrm{O}_{7}$, has been isolated from a benthic dinoflagellate Amphidinium sp. (strain HYA024) [17]. The gross structure of $\mathbf{4 0}$ was mainly elucidated on the basis of 2D NMR data. The relative stereochemistry of 40 was deduced from detailed analyses of bond rotations based on ${ }^{1} \mathrm{H}-{ }^{1} \mathrm{H}$ and ${ }^{13} \mathrm{C}-{ }^{1} \mathrm{H}$ coupling constants and ROESY correlations. The absolute stereochemistry of $\mathbf{4 0}$ was assigned by a modified Mosher's method. 
Table 1 Lactone ring size, isolation yields, and cytotoxicity data for amphidinolides $A \sim H, J \sim S, T 1, U \sim Y(\mathbf{1} \sim \mathbf{8}, \mathbf{9} \sim \mathbf{1 8}, \mathbf{1 9}$, and 20 24, respectively), B4 (35), B5 (36), B6 (45), B7 (44), and C2 (37), amphidinolactones A (38) and B (39), and iriomoteolides 1a (40), 1b (41), 1c (42), and 3a (43)

\begin{tabular}{|c|c|c|c|c|c|c|c|c|c|c|c|c|c|}
\hline \multirow{3}{*}{ Compd. } & \multirow{3}{*}{$\begin{array}{l}\text { Lactone } \\
\text { ring size }\end{array}$} & \multicolumn{10}{|c|}{ Isolation yields (10 $\left.{ }^{-4} \%\right)$} & \multirow{2}{*}{\multicolumn{2}{|c|}{$\begin{array}{l}\text { Cytotoxicity } \\
\left(\mathrm{IC}_{50,}, \mu \mathrm{g} / \mathrm{ml}\right)\end{array}$}} \\
\hline & & \multicolumn{10}{|c|}{ Strain no. ${ }^{a}$} & & \\
\hline & & Y-5 & $\mathrm{Y}-25$ & Y-26 & Y-42 & Y-56 & Y-71 & Y-72 & Y-100 & HYA002 & HYA024 & $\mathrm{L} 1210^{c}$ & $\mathrm{~KB}^{d}$ \\
\hline 1 & 20 & 20 & & & & & & & & & & 2.0 & 5.7 \\
\hline 2 & 26 & 10 & 0.8 & & & & 17 & & & & & 0.00014 & 0.0042 \\
\hline 35 & 26 & & & & & & & & 8 & & & 0.00012 & 0.001 \\
\hline 36 & 26 & & & & & & & & 2 & & & 0.0014 & 0.004 \\
\hline 45 & 26 & & & & & & & & & 30 & & $g$ & $g$ \\
\hline 44 & 26 & & & & & & & & & 30 & & $g$ & $g$ \\
\hline 3 & 25 & 15 & & 0.3 & & & 9 & 12 & & & & 0.0058 & 0.0046 \\
\hline 37 & 25 & & & & & & 1.5 & & & & & 0.8 & 3 \\
\hline 4 & 26 & 4 & & & & & & & & & & 0.019 & 0.08 \\
\hline 5 & 19 & 4 & & & & & & & & & & 2.0 & 10 \\
\hline 6 & 25 & & & 0.1 & & & 6 & & & & & 1.5 & 3.2 \\
\hline 7 & 27 & & 20 & & 8 & & & 46 & & & & 0.0054 & 0.0059 \\
\hline 8 & 26 & & 17 & & 7 & & & 82 & & 300 & & 0.00048 & 0.0005 \\
\hline 9 & 15 & 60 & & & & & & & & & & 2.7 & 3.9 \\
\hline 10 & 19 & 0.3 & & & & & & & & & & 1.65 & 2.9 \\
\hline 11 & 27 & & 2 & & & & & & & & & 0.092 & 0.1 \\
\hline 12 & 29 & 4 & & & & & & & & & & 1.1 & 0.44 \\
\hline 13 & 26 & 9 & & & & & & & & & & 0.00005 & 0.00006 \\
\hline 14 & 15 & 1 & & & & & & & & & & 1.7 & 3.6 \\
\hline 15 & 15 & 2 & & & & & & & & & & 1.6 & 5.8 \\
\hline 16 & 12 & 0.5 & & & & & & & & & & 6.4 & $>10$ \\
\hline 17 & 15 & 5 & & & & & & & & & & 1.4 & 0.67 \\
\hline 18 & 16 & 1 & & & & & & & & & & 4.0 & 6.5 \\
\hline 19 & 19 & & & & & 50 & 9.2 & & & & & 18 & $>20$ \\
\hline 20 & 20 & & & & & 2 & & & & & & 12 & $>20$ \\
\hline 21 & 14 & 0.5 & & & & & & & & & & 3.2 & 7 \\
\hline 22 & 12 & & & & 90 & & & & & & & 3.9 & $>10$ \\
\hline 23 & $16^{e}$ & & & & 4 & & & & & & & 0.6 & 7.5 \\
\hline 24 & 17 & & & & 7 & & & & & & & 0.8 & 8.0 \\
\hline 38 & 13 & 0.1 & & & & & & & & & & 8 & $>10$ \\
\hline 39 & 26 & 0.1 & & & & & & & & & & 3.3 & 5.3 \\
\hline 40 & 20 & & & & & & & & & & $280^{f}$ & $g$ & $g$ \\
\hline 41 & 20 & & & & & & & & & & $20^{f}$ & $g$ & $g$ \\
\hline 42 & 20 & & & & & & & & & & $70^{f}$ & $g$ & $g$ \\
\hline 43 & 15 & & & & & & & & & & $150^{f}$ & $g$ & $g$ \\
\hline
\end{tabular}

${ }^{a}$ Amphidinium sp. ${ }^{b} 50 \%$ inhibition concentration. ${ }^{c}$ Murine lymphoma cells. ${ }^{d}$ Human epidermoid carcinoma cells. ${ }^{e}$ Macrodiolide. ${ }^{f}$ Dry weight. ${ }^{g}$ not tested.

Two cytotoxic 20-membered macrolides, iriomoteolides $1 \mathrm{~b}$ (41) and 1c (42), $\mathrm{C}_{29} \mathrm{H}_{46} \mathrm{O}_{7}$ and $\mathrm{C}_{30} \mathrm{H}_{48} \mathrm{O}_{7}$, respectively, have been also isolated from the same dinoflagellate Amphidinium sp. as described above (strain HYA024) [18].

The gross structure of $\mathbf{4 2}$ was assigned as a homologue of 40 with a 4-hydroxy-3-methylpentyl side chain. Comparing ROESY data and ${ }^{1} \mathrm{H}-{ }^{1} \mathrm{H}$ coupling constants of $\mathbf{4 2}$ with those of $\mathbf{4 0}$, the relative stereochemistry of the macrocyclic ring portion for $\mathbf{4 2}$ was elucidated to be the same as that for 40. Although iriomoteolide 1b (41) might 


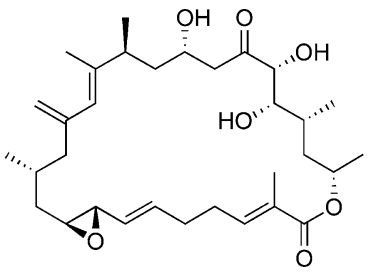

35

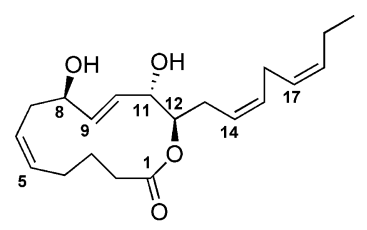

38

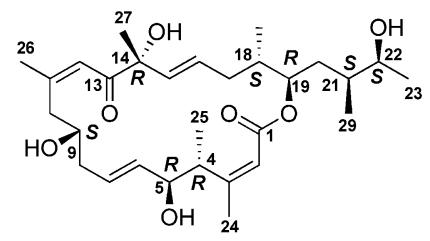

41

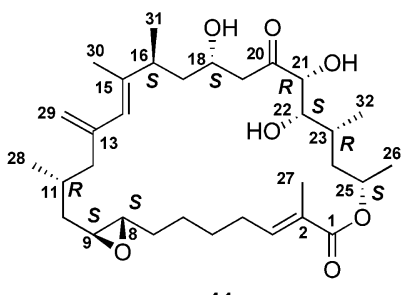

44<smiles>C=C(/C=C(\C)C[C@@H](C)CC(O)CC(=O)[C@H](O)[C@@H](O)C[C@@H](C)C[C@@H](C)OC(=O)/C(C)=C/CC/C=C/C1OC1C[C@@H]1CO1)CC(C)C</smiles>

36

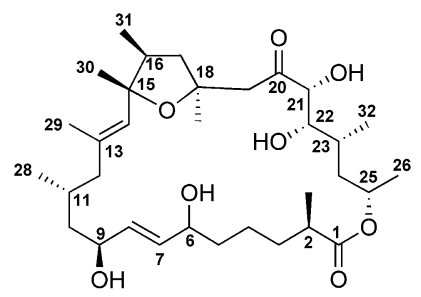

39

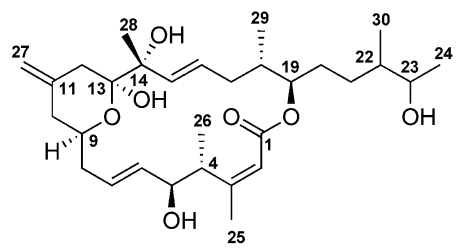

42

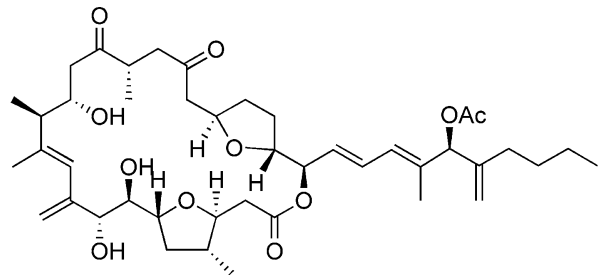

37

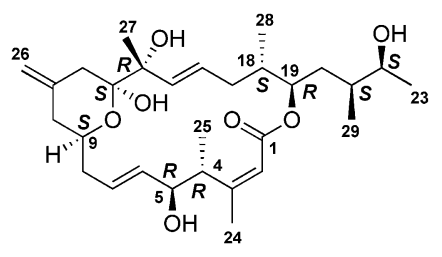

40

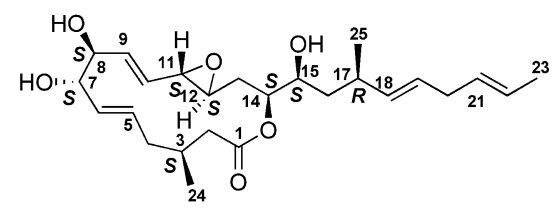

43 be an artifact generated from 40, interchange between 40 and 41 in $\mathrm{CHCl}_{3}$ or $\mathrm{MeOH}$ was not observed.

A cytotoxic 15-membered macrolide, iriomoteolide $3 \mathrm{a}$ (43), $\mathrm{C}_{25} \mathrm{H}_{38} \mathrm{O}_{6}$, has been isolated from the same dinoflagellate Amphidinium sp. as described above (strain HYA024) [27]. The gross structure of $\mathbf{4 3}$ was mainly elucidated on the basis of 2D NMR data. The relative stereochemistry of $\mathbf{4 3}$ was deduced from detailed analyses of bond rotations based on ${ }^{1} \mathrm{H}-{ }^{1} \mathrm{H}$ and ${ }^{13} \mathrm{C}-{ }^{1} \mathrm{H}$ coupling constants and NOESY correlations. The absolute stereochemistry of $\mathbf{4 3}$ was assigned by a modified Mosher's method.

\section{3-3. Amphidinolides B6 and B7}

Two cytotoxic 26-membered macrolides, amphidinolides B6 (45) and B7 (44), have been isolated from a symbiotic dinoflagellate Amphidinium sp. (strain HYA 002) [21]. The molecular formula of amphidinolide B7 (44) was assigned as $\mathrm{C}_{32} \mathrm{H}_{52} \mathrm{O}_{7}$, corresponding to the deoxy form of amphidinolide H4 (29). The gross structure of 44 was elucidated to be the 26-deoxy form of amphidinolide $\mathrm{H} 4$ (29) or amphidinolide $\mathrm{H} 5$ (30) on the basis of the ${ }^{1} \mathrm{H}-{ }^{1} \mathrm{H}$ COSY, TOCSY, HMQC, and HMBC spectra. The relative stereochemistry of amphidinolide B7 (44) was elucidated by comparison of the ${ }^{1} \mathrm{H}$ and ${ }^{13} \mathrm{C}$ chemical shifts and ${ }^{1} \mathrm{H}-{ }^{1} \mathrm{H}$ coupling constants of $\mathbf{4 4}$ with those of amphidinolides $\mathrm{H} 4$ (29) [22] and H5 (30) [22]. The CD spectrum for 44 
corresponded to those for amphidinolides $\mathrm{H}(\mathbf{8})$ and B4 (35) [23]. Therefore, the absolute configurations of amphidinolide B7 (44) were proposed to be as shown.

The molecular formula of amphidinolide B6 (45), $\mathrm{C}_{32} \mathrm{H}_{54} \mathrm{O}_{8}$, was revealed by HRESI-MS data $[\mathrm{m} / \mathrm{z} 589.3718$ $(\mathrm{M}+\mathrm{Na})^{+}, \Delta+0.2 \mathrm{mmu}$. The gross structure of amphidinolide B6 was assigned as $\mathbf{4 5}$ on the basis of the ${ }^{1} \mathrm{H}-{ }^{1} \mathrm{H}$ COSY, TOCSY, HMQC, and HMBC spectra. The relative stereochemistry of amphidinolide B6 (45) was elucidated by comparison of the ${ }^{1} \mathrm{H}$ and ${ }^{13} \mathrm{C}$ chemical shifts and ${ }^{1} \mathrm{H}-{ }^{1} \mathrm{H}$ coupling constants of 45 with those of amphidinolides H4 (29) and H5 (30). The CD spectrum of 45 was similar to those of amphidinolides $\mathrm{H}(\mathbf{8})$ and B4 (35) [23]. Therefore, the absolute configurations of $\mathbf{4 5}$ were proposed to be as shown.

\section{Synthetic Studies of Amphidinolides}

\section{4-1. Amphidinolide E}

Amphidinolide E (5) is a cytotoxic 19-membered macrolide possessing a tetrahydrofuran ring, four $\mathrm{C}_{1}$ branches, and three hydroxyl groups [24]. The stereochemistry of eight chiral centers in $\mathbf{5}$ remained unresolved due to lack of sample. Recently, we assigned the absolute stereochemistry of 5 by using a sample $(2.0 \mathrm{mg})$ obtained through repeated cultivation [28]. The total synthesis of amphidinolide E (5) was achieved by Roush group, via a [3+2] annulation reaction of aldehyde 47 and allylsilane 48 followed by olefin metathesis of 46 as a key step (Scheme 1) [29]. Recently, Lee and co-workers synthesized amphidinolide E (5) using macrolactonization of 49 through Julia coupling of $\mathbf{5 0}$ and $\mathbf{5 1}$ derived from $\mathbf{5 2}$ via a radical cyclization of a $\beta$-alkoxy acrylate (Scheme 2) [30]. The total synthesis by

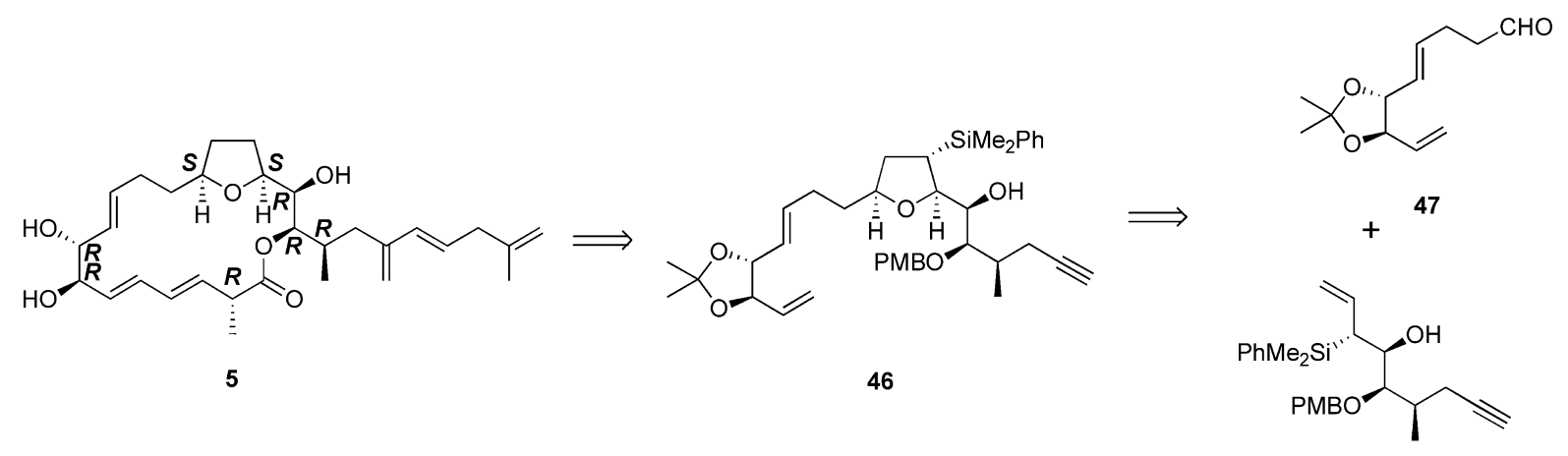

Scheme 1 Retrosynthetic analysis of amphidinolide E (5) by Roush's group.

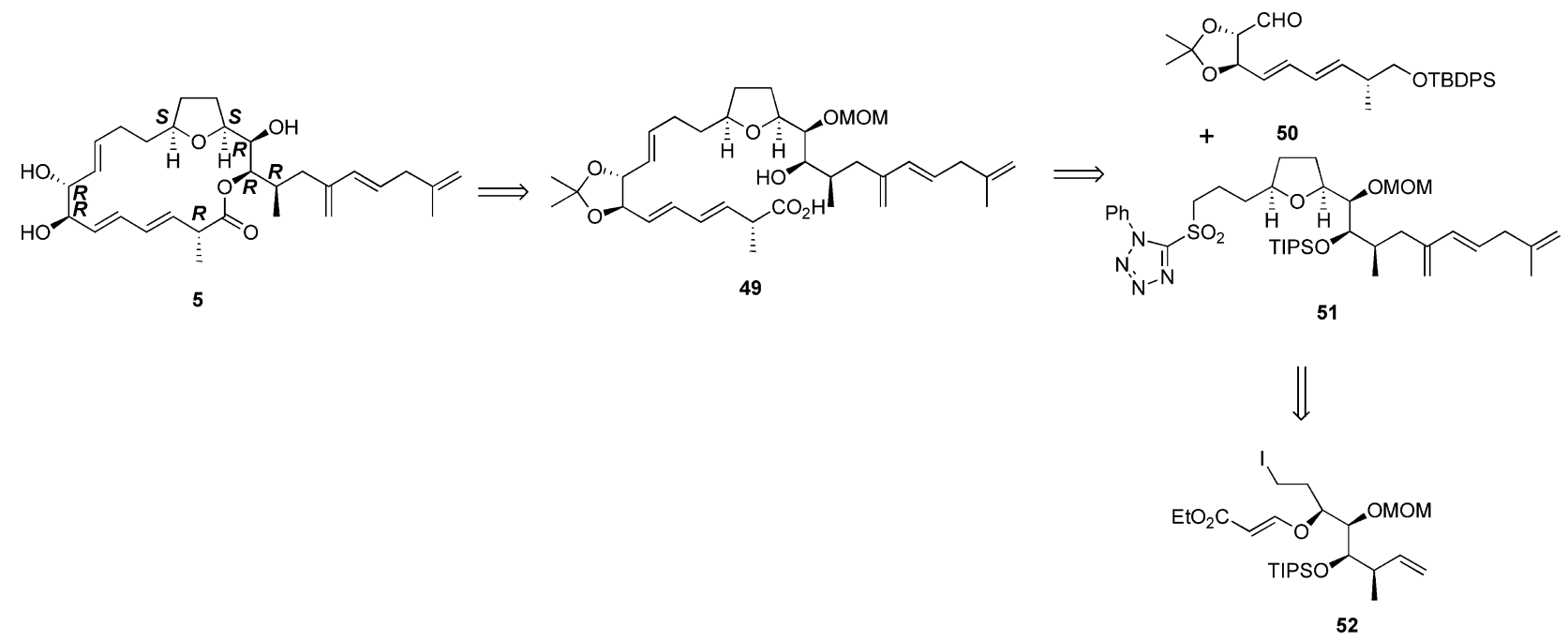

Scheme 2 Retrosynthetic analysis of amphidinolide E (5) by Lee's group. 


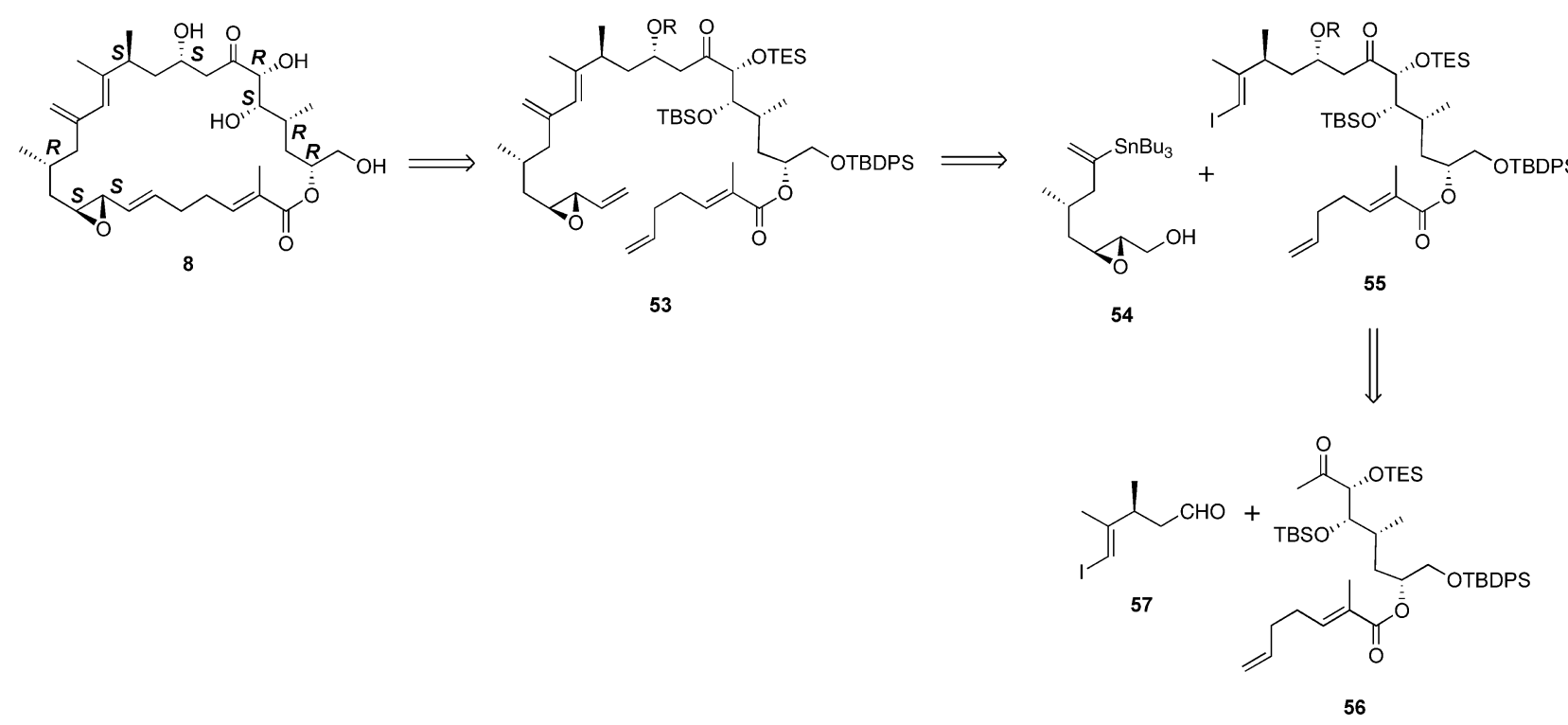

Scheme 3 Retrosynthetic analysis of amphidinolide H (8) by Fürstner's group.

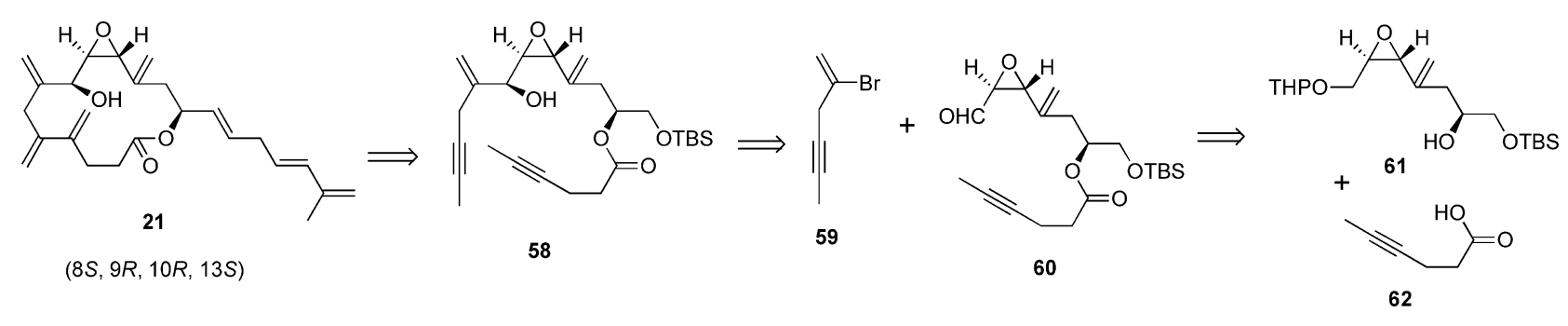

Scheme 4 Retrosynthetic analysis of amphidinolide $V(\mathbf{2 1})$ by Fürstner's group.

these two groups confirmed the proposed structure [28].

\section{4-2. Amphidinolide $H$}

Amphidhinolide $\mathrm{H}$ (8) is a 26-membered macrolide possessing an epoxide, six $\mathrm{C}_{1}$ branches, and four hydroxyl groups with potent cytotoxicity against L1210 and KB cells ( $\mathrm{IC}_{50}: 0.00048$ and $0.00052 \mu \mathrm{g} / \mathrm{ml}$, respectively) $[25,26]$. The relative configurations at nine chiral centers in $\mathbf{8}$ were deduced from a single crystal X-ray diffraction analysis. The absolute stereochemistry of amphidinolide $\mathrm{H}(\mathbf{8})$ was assigned by comparison of the ${ }^{1} \mathrm{H}-\mathrm{NMR}$ data of the tris- $(S)$ MTPA ester of the C-22 C-26 segment derived from natural 8 with those of tris- $(S)$ - and - $(R)$-MTPA esters of the C-22 C-26 segment synthesized from methyl (2S)-3hydroxy-2-methyl-propionate [26]. Recently, Fürstner and co-workers synthesized amphidinolide $\mathrm{H}(\mathbf{8})$ using ring closing metathesis of $\mathbf{5 3}$ through $s p^{2}-s p^{2}$ Stille coupling reaction between $\mathbf{5 4}$ and $\mathbf{5 5}$ derived from $\mathbf{5 6}$ and $\mathbf{5 7}$, respectively, via aldol reaction (Scheme 3) [31].

\section{4-3. Amphidinolide $V$}

A cytotoxic 14-membered macrolide, amphidinolide $\mathrm{V}$ (21), possesses five exo-methylenes and one epoxide. The relative configurations at four chiral centers in $\mathbf{2 1}$ were deduced from ${ }^{1} \mathrm{H}-{ }^{1} \mathrm{H}$ coupling constants and NOESY data [32].

Fürstner and co-workers synthesized amphidinolide $\mathrm{V}$ (21) using ring-closing alkyne metathesis of $\mathbf{5 8}$ through chelation-controlled additions of $\mathbf{5 9}$ and $\mathbf{6 0}$ derived from $\mathbf{6 1}$ and 62, respectively, via an esterification (Scheme 4) [33]. As a result, the relative stereochemistry of amphidinolide $\mathrm{V}$ (21) was proposed as shown.

\section{4-4. Amphidinolide N}

The structure of amphidinolide N (13) [34] was interpreted to be a 26 -membered macrolide containing a 6-membered hemiacetal ring, an epoxide, a ketone carbonyl, four $\mathrm{C}_{1}$ branches, and seven hydroxyl groups. This compound was extremely cytotoxic against $\mathrm{L} 1210$ and $\mathrm{KB}$ cells $\left(\mathrm{IC}_{50}\right.$ : 0.00005 and $0.00006 \mu \mathrm{g} / \mathrm{ml}$, respectively). Although the relative configurations at $\mathrm{C}-14, \mathrm{C}-15, \mathrm{C}-16$, and $\mathrm{C}-19$ were 


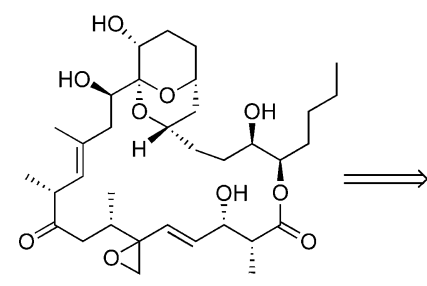

63

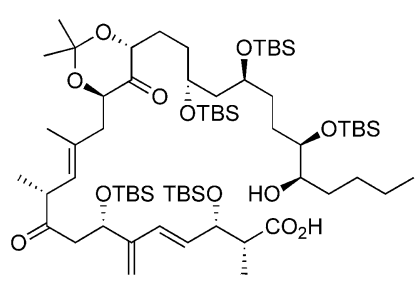

64
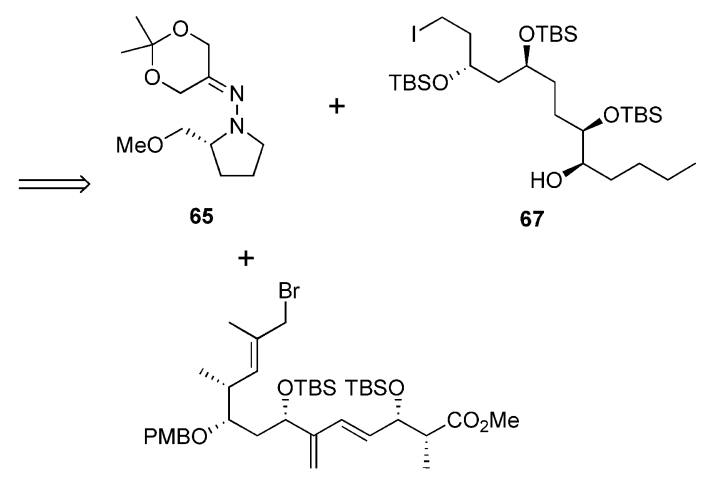

66

Scheme 5 Retrosynthetic analysis of iso-epoxy-amphidinolide N (63) by Nicolaou's group.

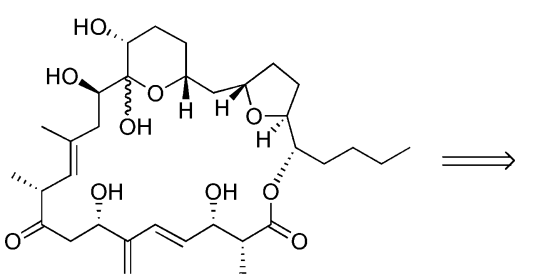

68

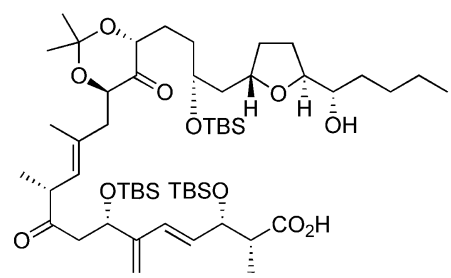

69

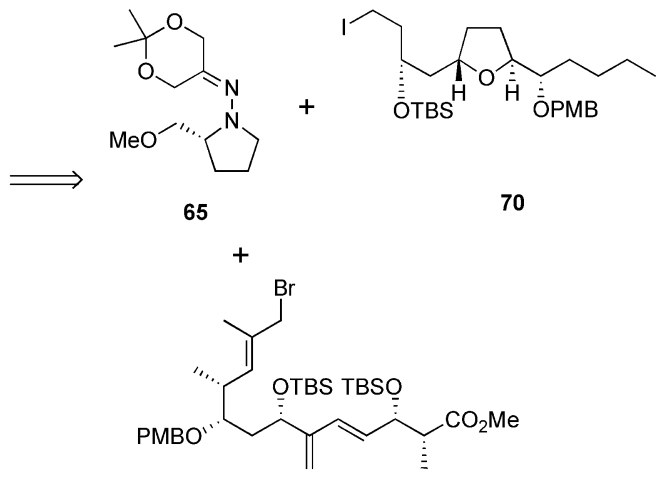

66

Scheme 6 Retrosynthetic analysis of des-epoxy-caribenolide I (68) by Nicolaou's group.

indicated as shown, the other relative stereochemistry as well as the absolute stereochemistry of $\mathbf{1 3}$ have not been determined. Shimizu and co-workers isolated an amphidinolide N-type macrorolide, named caribenolide I [35], from a free-swimming dinoflagellate Amphidinium operculatum ver nov Gibbosum, which showed antitumor activity against murine leukemia $\mathrm{P} 388$ in vivo.

Nicolaou and co-workers have succeeded in synthesis of iso-epoxy-amphidinolide $\mathrm{N}$ (63) using macrolactonization of 64 via Enders hydrazone alkylation of three subunits $\mathbf{6 5} \sim \mathbf{6 7}$ (Scheme 5) [36, 37]. Nicolaou's group has also achieved the synthesis of des-epoxy-caribenolide I (68) using macrolactonization of $\mathbf{6 9}$ via Enders hydrazone alkylation of three subunits $\mathbf{6 5}, \mathbf{6 6}$, and $\mathbf{7 0}$ (Scheme 6) [36, 37]. Figadere and co-workers synthesized the $\mathrm{C}-1 \sim \mathrm{C}-11$ [38] and the C-13 C-29 segments of caribenolide I [39].

\section{4-5. Amphidinolides $X$ and $Y$}

Amphidinolide X (23) [40] is a cytotoxic 16-membered macrolide consisting of polyketide-drived diacid and diol units. The absolute configurations at $\mathrm{C}-10$ and $\mathrm{C}-17$ were elucidated to be $S$ and $R$, respectively, by application of a modified Mosher's method. A $4 S$-configuration was deduced from comparison of ${ }^{1} \mathrm{H}-\mathrm{NMR}$ data of MTPA esters of the C-1 C-6 segments of the synthetic 1,6-bis- $(R)$ MTPA ester. The structure of amphidinolide Y (24) [41] was interpreted to be a cytotoxic 17 -membered macrolide existing as a 9:1 equilibrium mixture of 6-keto and 6(9)hemiacetal forms (24a and $\mathbf{2 4 b}$, respectively). The absolute stereochemistry of the 6-keto form (24a) was assigned on the basis of the spectroscopic data and chemical conversion of 24 into amphidinolide $\mathrm{X}(\mathbf{2 3})$ by $\mathrm{Pb}(\mathrm{OAc})_{4}$ oxidation.

Fürstner and co-workers synthesized amphidinolide $\mathrm{X}$ (23) using macrolactonization of $\mathbf{7 1}$ through alkyl-Suzuki reaction of $\mathbf{7 3}$ and $\mathbf{7 2}$ derived from $\mathbf{7 4}$ and $\mathbf{7 5}$, respectively, via esterification (Scheme 7) [42]. Amphidinolide Y (24) was also synthesized by Fürstner's group via macrolactonization of $\mathbf{7 6}$ through alkyl-Suzuki reaction of 73 and 77 (Scheme 8) [42]. The absolute stereochemistry of amphidinolides X (23) and Y (24) was confirmed through these total synthesis. Recently, Dai and co-workers also synthesized amphidinolide Y (24) via ring-closing 


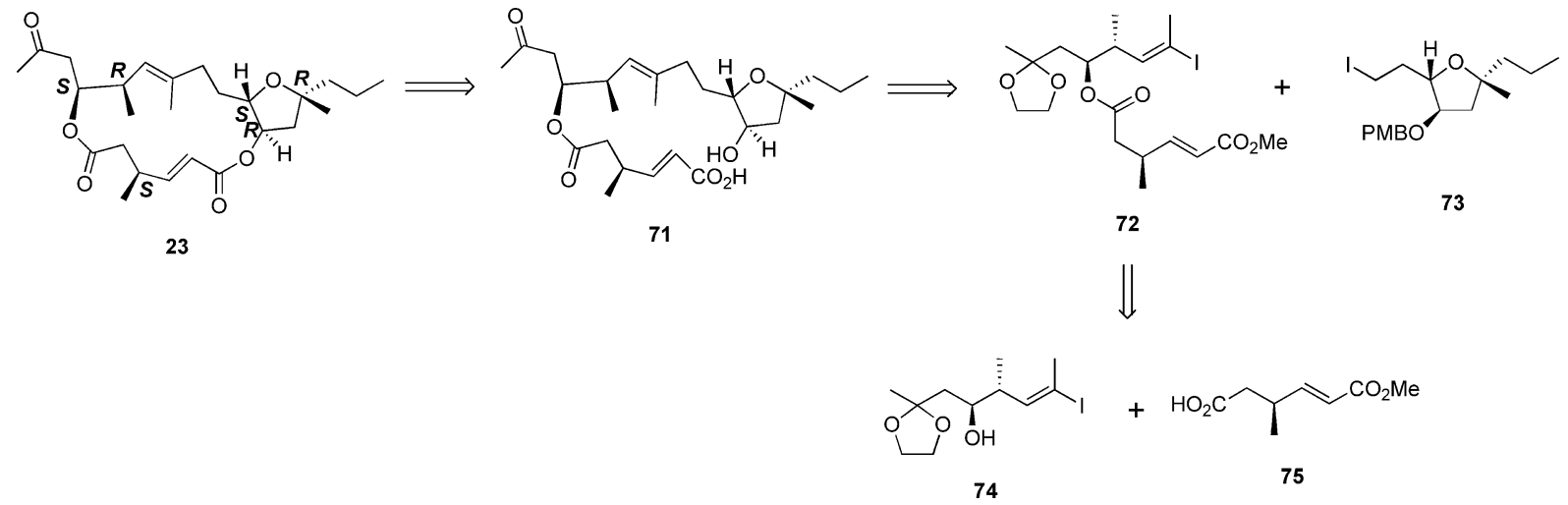

Scheme 7 Retrosynthetic analysis of amphidinolide X (23) by Fürstner's group.

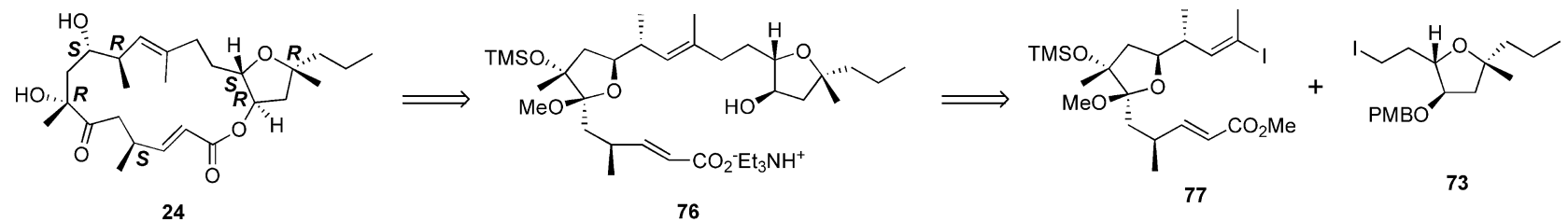

Scheme 8 Retrosynthetic analysis of amphidinolide Y (24) by Fürstner's group.

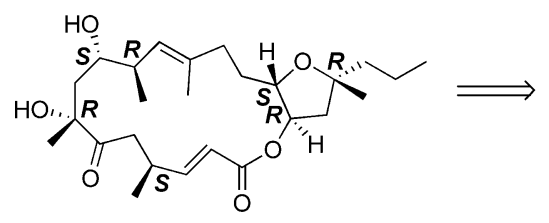

24

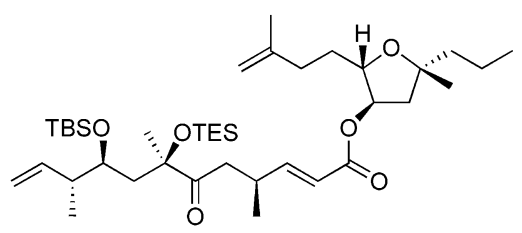

78

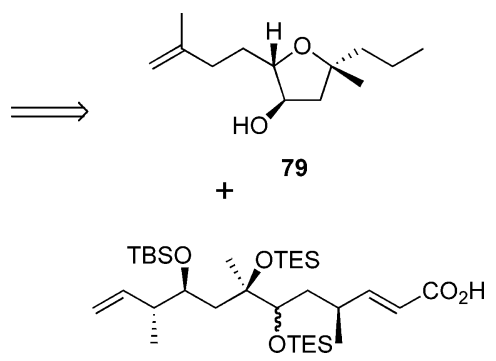

80

Scheme 9 Retrosynthetic analysis of amphidinolide $Y(\mathbf{2 4})$ by Dai's group.

metathesis of $\mathbf{7 8}$ through esterification of $\mathbf{7 9}$ and $\mathbf{8 0}$ (Scheme 9) [43].

\section{Mechanism of Action of Amphidinolides B and H}

Amphidinolide B (2) increased the ATPase activity of myofibrils and natural actomyosin. The ATPase activity of actomyosin reconstituted from actin and myosin was enhanced in a concentration-dependent manner in the presence or absence of troponin-tropomyosin complex. $\mathrm{Ca}^{2+}$-, $\mathrm{K}^{+}$-EDTA- or $\mathrm{Mg}^{2+}$-ATPase of myosin was not affected by 2 . These results suggest that amphidinolide $B$ (2) enhances an interaction of actin and myosin directly and increases $\mathrm{Ca}^{2+}$ sensitivity of the contractile apparatus mediated through troponin-tropomyosin system, resulting in an increase in the ATPase activity of actomyosin and thus enhances the contractile response of myofilament [44].

The molecular target of amphidinolide $H(8)[25,26]$ has been investigated as follows [45, 46]. The analysis of phenotypes of amphidinolide H-treated cells suggested that amphidinolide $\mathrm{H}(\mathbf{8})$ disrupt the actin organization in the cells, and the polymerization/depolymerization assay using purified actin indicated that amphidinolide $\mathrm{H}(\mathbf{8})$ stimulated actin polymerization and stabilized F-actin. MALDI-TOF mass analysis and the halo assay using the yeast harboring site-directed mutagenized actin revealed that the covalent binding of amphidinolide $\mathrm{H}(\mathbf{8})$ to actin and the binding site was Tyr200 of actin subdomain 4. Time-lapse analyses showed that amphidinolide $\mathrm{H}(\mathbf{8})$ stimulated the formation 
of small actin patches, followed by F-actin rearrangement into aggregates via the retraction actin fibers. These results indicated that amphidinolide $\mathrm{H} \mathrm{(8)}$ is a novel F-actin stabilizer that covalently binds on actin [45].

To evaluate whether amphidinolide $\mathrm{H}(\mathbf{8})$ competes at the same binding site with phalloidin, the effect of $\mathbf{8}$ on phalloidin-actin binding was measured using fluorescein isothiocyanate conjugated phalloidin. Amphidinolide H (8) does not compete with, instead enhances, the binding of phalloidin to F-actin, indicating that $\mathbf{8}$ increased susceptibility of F-actin to phalloidin [46].

\section{Biosynthetic Studies of Amphidinolides}

The ${ }^{13} \mathrm{C}$-labeling patterns for amphidinolides B (2), C (3), G (7), H (8), J (9), T1 (19), W (22), X (23), and Y (24) by feeding experiments using ${ }^{13} \mathrm{C}$-labeled acetates for some amphidinolide producers are shown in Fig. 2 [6]. The incorporation patterns for these amphidinolides revealed that the main chain of these macrolides was generated from unusual units derived only from $\mathrm{C}-2$ of acetates in addition to successive polyketide chains. The experiments also showed that all $\mathrm{C} 1$ branched carbons were derived from C-2 of acetates and attached to C-1 of intact acetate or isolated $\mathrm{C}-2$ of acetate. These unusual incorporation

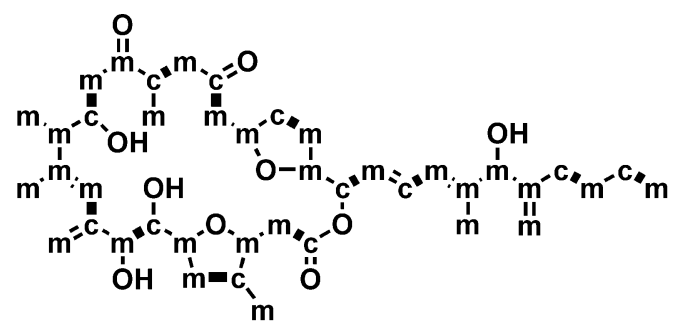

3

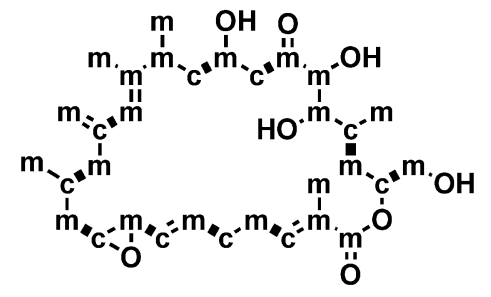

8

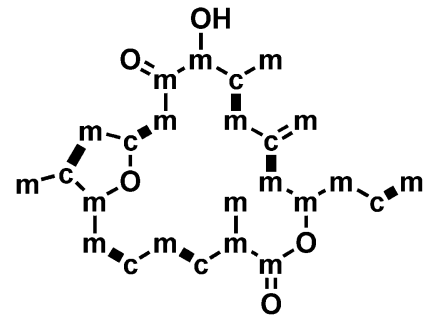

19

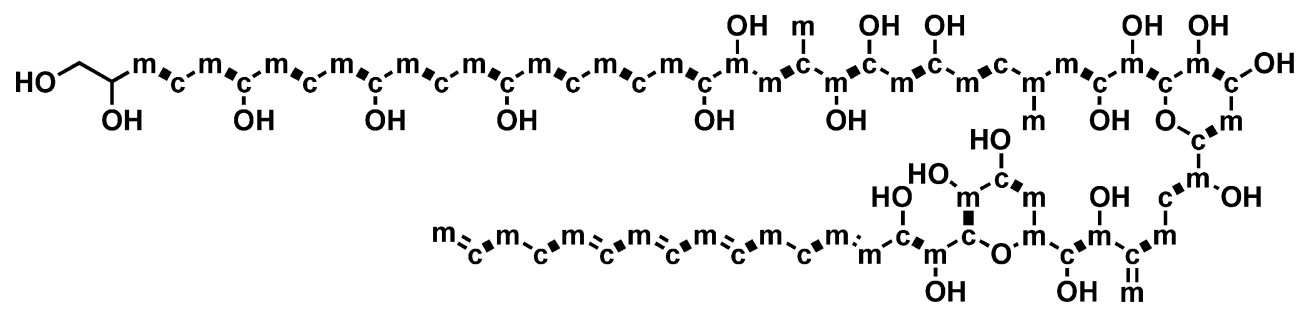

81

Fig. 2 Acetate-incorporation patterns of amphidinolides C (3), H (8), and T1 (19), and amphidinol 4 (81). 
patterns could be found in most of dinoflagellate polyketides [9]. For example, a similar labeling pattern of amphidinol 4, a long chain polyene-polyhydroxy compound isolated from Amphidinium klebsii, has been reported by Murata and co-workers (Fig. 2) [47].

HCS-like gene cassette has been identified in the curacin $A$ and jamaicamide biosynthetic genes from a cyanobacterium Lyngbya majuscula [48, 49], the mupirocin biosynthesis gene from Pseudomonas fluorescens, and the bacillaene biosynthesis gene from Bacillus subtilis, and is proposed to catalyze addition of $\mathrm{C}-2$ from acetate onto the polyketide chain to generate a pendant functional group [50]. The pendant methyl groups in dinoflagellate polyketides might be constructed by similar genes to HCSlike gene cassette.

Rein and co-workers amplified approximately 700-bp DNA fragments homologous with $\beta$-ketoacyl synthase domains in known type I PKSs from seven different species of dinoflagellates by polymerase chain reaction (PCR). They reported the localization of polyketide synthase (PKS) genes by a combination of flow cytometry/PCR and fluorescence in situ hybridization (FISH). However, these genes have not yet been linked to dinoflagellate polyketide production $[51,52]$.

We have attempted to clone the PKS gene responsible for amphidinolide biosynthesis from a dinoflagellate Amphidinium sp. (strain Y-42). Fourteen $\beta$-ketoacyl synthase genes were obtained by PCR amplification using degenerated primer sets designed from the conserved amino acid sequences of $\beta$-ketoacyl synthase domains in known type I PKSs. The PCR analysis revealed that these DNA sequences exist only in the amphidinolide producer. The deduced gene products for insert DNA of a positive clone, which was isolated from the genomic DNA library of Amphidinium sp. (strain Y-42), showed similarity to $\beta$-ketoacyl synthase, acyl transferase, dehydratase, ketoreductase, acyl carrier protein, and thioesterase in known type I PKSs [53].

\section{Conclusions}

Recent studies on cytotoxic macrolides, amphidinolides, from dinoflagellates Amphidinium sp. indicate that they are expected to be hopeful drug leads or bioprobes useful for basic research in life sciences. The stereochemistry of some amphidinolides remains undefined due to their poor productivity, while the absolute stereochemistry of some amhidinolides has been determined through their total synthesis. Among all the amphidinolides isolated so far, amphidinolides $\mathrm{H}(\mathbf{8})$ and $\mathrm{N}(\mathbf{1 3})$ exhibit remarkably potent cytotoxicity against human tumor cell lines and are expected to be hopeful lead compounds for new anticancer drugs. Though the mechanism of action of amphidinolide $\mathrm{H} \mathrm{(8)}$ has been studied well, those of other amphidinolides remain to be defined. For further biological testing, the poor productivity of these macrolides needs to be considerably improved. One of the approaches is to identify the polyketide synthase in dinoflagellate Amphidinium sp., although it is quite difficult to identify it from the huge genome of the dinoflagellate. Further development of the cell biology and molecular biology of dinoflagellates is required for biomedical and pharmaceutical application of the amphidinolides.

\section{References}

1. Kobayashi J, Ishibashi M. Bioactive metabolites of symbiotic marine microorganisms. Chem Rev 93: 1753-1769 (1993)

2. Kobayashi J, Ishibashi M. Amphidinolides: Unique macrolides from marine dinoflagellates. Heterocycles 44: 543-572 (1997)

3. Ishibashi M, Kobayashi J. Miscellaneous Natural Products Including Marine Products, Pheromones, Plant Hormones, and Aspects of Ecology. In Comprehensive Natural Products Chemistry, Vol. 8. Ed., K. Mori, pp. 415-650, Elsevier Science, Oxford, UK (1999)

4. Kobayashi J, Tsuda M, Ishibashi M. Bioactive products from marine micro- and macro-organisms. Pure Appl Chem 71: 1123-1126 (1999)

5. Kobayashi J, Shimbo K, Kubota T, Tsuda M. Bioactive macrolides and polyketides from marine dinoflagellates. Pure Appl Chem 75: 337-342 (2003)

6. Kobayashi J, Tsuda M. Amphidinolides, bioactive macrolides from symbiotic marine dinoflagellates. Nat Prod Rep 21: 77-93 (2004)

7. Kobayashi J, Kubota T. Bioactive macrolides and polyketides from marine dinoflagellates of the genus Amphidinium. J Nat Prod 70: 451-460 (2007)

8. Chakraborty TK, Das S. Chemistry of potent anti-cancer compounds, amphidinolides. Curr Med Chem Anti-cancer Agents 1: 131-149 (2001)

9. Moore BS. Biosynthesis of marine natural products: microorganisms and macroalgae. Nat Prod Rep 16: 653-674 (1999)

10. Shimizu Y. Microalgal metabolites. Curr Opin Microbiol 6: 236-243 (2003)

11. Daranas AH, Norte M, Fernandez JJ. Toxic marine microalgae. Toxicon 39: 1101-1132 (2001)

12. Rein KS, Borrone J. Polyketides from dinoflagellates: origins, pharmacology and biosynthesis. Comp Biotechnol Physiol B: Biochem Mol Biol 124: 117-131 (1999)

13. Yasumoto T, Satake M. Bioactive compounds from marine 
microalgae. Chimia 52: 63-68 (1998)

14. Yasumoto T, Satake M. Chemistry, etiology and determination methods of ciguatera toxins. J Toxicol Toxin Rev 15: 91-107 (1996)

15. Takahashi Y, Kubota T, Kobayashi J. Amphidinolactone A, a new 13-membered macrolide from dinoflagellate Amphidinium sp. Heterocycles 72: 567-572 (2007)

16. Takahashi Y, Kubota T, Kobayashi J. Amphidinolactone B, a new 26-membered macrolide from dinoflagellate Amphidinium sp. J Antibiot 60: 376-379 (2007)

17. Tsuda M, Oguchi K, Iwamoto R, Okamoto Y, Kobayashi J, Fukushi E, Kawabata J, Ozawa T, Masuda A, Kitaya Y, Omasa K. Iriomoteolide-1a, a potent cytotoxic 20membered macrolide from a benthic dinoflagellate Amphidinium species. J Org Chem 72: 4469-4474 (2007)

18. Tsuda M, Oguchi K, Iwamoto R, Okamoto Y, Fukushi E, Kawabata J, Ozawa T, Masuda A. Iriomoteolides-1b and -1c, 20-membered macrolides from a marine dinoflagellate Amphidinium species. J Nat Prod 70: 1661-1663 (2007)

19. Tsuda M, Endo T, Kobayashi J. Amphidinolide T, novel 19-membered macrolide from marine dinoflagellate Amphidinium sp. J Org Chem 65: 1349-1352 (2000)

20. Kobayashi J, Kubota T, Endo T, Tsuda M. Amphidinolides T2, T3, and T4, new 19-membered macrolides from the dinoflagellate Amphidinium sp. and the biosynthesis of amphidinolide T1. J Org Chem 66: 134-142 (2001)

21. Oguchi K, Tsuda M, Iwamoto R, Okamoto Y, Endo T, Kobayashi J, Ozawa T, Masuda A. Amphidinolides B6 and B7, cytotoxic macrolides from a symbiotic dinoflagellate Amphidinium species. J Nat Prod 70: 1676-1679 (2007)

22. Kobayashi J, Shimbo K, Sato M, Tsuda M. Amphidinolides $\mathrm{H} 2 \sim \mathrm{H} 5, \mathrm{G} 2$, and G3, new cytotoxic 26- and 27-membered macrolides from dinoflagellate Amphidinium sp. J Org Chem 67: 6585-6592 (2002)

23. Tsuda M, Kariya Y, Iwamoto R, Fukushi E, Kawabata J, Kobayashi J. Amphidinolides B4 and B5, potent cytotoxic 26-membered. macrolides from dinoflagellate Amphidinium species. Mar Drugs 3: 1-8 (2005)

24. Kobayashi J, Ishibashi M, Murayama T, Takamatsu M, Iwamura M, Ohizumi Y, Sasaki T. Amphidinolide E, a novel antileukemic 19-membered macrolide from the cultured symbiotic dinoflagellate Amphidinium sp. J Org Chem 55: 3421-3423 (1990)

25. Kobayashi J, Shigemori H, Ishibashi M, Yamasu T, Hirota H, Sasaki T. Amphidinolides G and H: New potent cytotoxic macrolides from the cultured symbiotic dinoflagellate Amphidinium sp. J Org Chem 56: 5221-5224 (1991)

26. Kobayashi J, Shimbo K, Sato M, Shiro M, Tsuda M. Absolute stereochemistry of amphidinolides G and H. Org Lett 2: 2805-2807 (2000)

27. Oguchi K, Tsuda M, Iwamoto R, Okamoto Y, Kobayashi J, Fukushi E, Kawabata J, Ozawa T, Masuda A, Kitaya Y, Omasa K. Iriomoteolide-3a, a cytotoxic 15-membered macrolide from a marine dinoflagellate Amphidinium species. J Org Chem 73: 1567-1570 (2008)
28. Kubota T, Tsuda M, Kobayashi J. Absolute stereochemistry of amphidinolide E. J Org Chem 67: 1651-1656 (2002)

29. Va P, Roush WR. Total synthesis of amphidinolide E. J Am Chem Soc 128: 15960-15961 (2006)

30. Kim CH, An HJ, Shin WK, Yu W, Woo SK, Jung SK, Lee E. Total synthesis of (-)-amphidinolide E. Angew Chem Int Ed 45: 8019-8021 (2006)

31. Fürstner A, Bouchez LC, Fune JA, Liepins V, Porée FH, Gilmour R, Beaufils F, Laurich D, Tamiya M. Total syntheses of amphidinolide $\mathrm{H}$ and G. Angew Chem Int Ed 46: 9265-9270 (2007)

32. Kubota T, Tsuda M, Kobayashi J. Amphidinolide V, novel 14-membered macrolide from marine dinoflagellate Amphidinium sp. Tetrahedron Lett 41: 713-716 (2000)

33. Fürstner A, Larionov O, Flügge $\mathrm{S}$. What is Amphidinolide V? Report on a likely conquest. Angew Chem Int Ed 46: 5545-5548 (2007)

34. Ishibashi M, Yamaguchi N, Sasaki T, Kobayashi J. Amphidinolide N, a novel 26-membered macrolide with remarkably potent cytotoxicity from the cultured marine dinoflagellate Amphidinium sp. J Chem Soc Chem Commun 1445-1446 (1994)

35. Bauer I, Maranda L, Young KA, Shimizu Y, Fairchild C, Cornell L, MacBeth J, Huang S. Isolation and structure of caribenolide I, a highly potent antitumor macrolide from a cultured free-swimming caribbean dinoflagellate, Amphidinium sp. S1-36-5. J Org Chem 60: 1084-1086 (1995)

36. Nicolaou KC, Brenzovich WE, Bulger PG, Francis TM. Synthesis of iso-epoxy-amphidinolide $\mathrm{N}$ and des-epoxycaribenolide I structures. Initial forays. Org Biomol Chem 4: 2119-2157 (2006)

37. Nicolaou KC, Bulger PG, Brenzovich WE. Synthesis of isoepoxy-amphidinolide $\mathrm{N}$ and des-epoxy-caribenolide I structures. Revised strategy and final stages. Org Biomol Chem 4: 2158-2183 (2006)

38. Seck M, Frank X, Seon-Meniel B, Hocquemiller R, Figadere B. A Baylis-Hillman approach to the synthesis of $\mathrm{C} 1 \sim \mathrm{C} 11$ fragment of caribenolide I. Tetrahedron Lett 47: 4175-4180 (2006)

39. Jalce G, Frank X, Seon-Meniel B, Hocquemiller R, Figadére B. Contribution to the total synthesis of caribenolide I. Tetrahedron Lett 47: 5905-5908 (2006)

40. Tsuda M, Izui N, Shimbo K, Sato M, Fukushi E, Kawabata J, Katsumata K, Horiguchi T, Kobayashi J. Amphidinolide $\mathrm{X}$, a novel 16-membered macrodiolide from dinoflagellate Amphidinium sp. J Org Chem 68: 5339-5345 (2003)

41. Tsuda M, Izui N, Shimbo K, Sato M, Fukushi E, Kawabata J, Kobayashi J. Amphidinolide Y, a novel 17-membered macrolide from dinoflagellate Amphidinium sp.: Plausible biogenetic precursor of amphidinolide X. J Org Chem 68: 9109-9112 (2003)

42. Fürstner A, Kattnig E, Lepage O. Total syntheses of amphidinolide X and Y. J Am Chem Soc 128: 9194-9204 (2006) 
43. Jin J, Chen Y, Li Y, Wu J, Dai WM. Total synthesis of amphidinolide $\mathrm{Y}$ by formation of trisubstituted $(E)$-double bond via ring-closing metathesis of densely functionalized alkenes. Org Lett 9: 2585-2588 (2007)

44. Matsunaga K, Nakatani K, Ishibashi M, Kobayashi J, Ohizumi Y. Amphidinolide B, a powerful activator of actomyosin ATPase enhances skeletal muscle contraction. Biochimica et Biophysica Acta 1427: 24-32 (1999)

45. Usui T, Kazami S, Dohmae N, Mashimo Y, Kondo H, Tsuda M, Terasaki GA, Ohashi K, Kobayashi J, Osada H. Amphidinolide $\mathrm{H}$, a potent cytotoxic macrolide, covalently binds on actin subdomain 4 and stabilizes actin filament. Chem Biol 11: 1269-1277 (2004)

46. Saito S, Feng J, Kira A, Kobayashi J, Ohizumi Y. Amphidinolide $\mathrm{H}$, a novel type of actin-stabilizing agent isolated from dinoflagellate. Biochem Biophys Res Commun 320: 961-965 (2004)

47. Houdai T, Matsuoka S, Murata M, Satake M, Ota S, Oshima Y, Rhodes L. Acetate labeling patterns of dinoflagellate polyketides, amphidinols 2, 3 and 4. Tetrahedron 57: 5551-5555 (2001)

48. Edwards DJ, Marquez BL, Nogle LM, Mcphail K, Goeger DE, Roberts MA, Gerwick WH. Structure and biosynthesis of the jamaicamides, new mixed polyketide-peptide neurotoxins from the marine cyanobacterium Lyngbya majuscula. Chem Biol 11: 817-833 (2004)

49. Hothersall J, Wu J, Rahman AS, Shields JA, Haddock J, Johnson N, Cooper SM, Stephens ER, Cox RJ, Crosby J, Willis CL, Simpson TJ, Thomas CM. Mutational analysis reveals that all tailoring region genes are required for production of polyketide antibiotic mupirocin by Pseudomonas fluorescens: Pseudomonic acid B biosynthesis precedes pseudomonic acid $A$. J Biol Chem 282: 15451-15461 (2007)

50. Gu L, Jia J, Liu H, Hakansson K, Gerwick WH, Sherman DH. Metabolic Coupling of Dehydration and Decarboxylation in the Curacin A Pathway: Functional Identification of a Mechanistically Diverse Enzyme Pair J Am Chem Soc 128: 9014-9015 (2006)

51. Snyder RV, Gibbs PDL, Palacios A, Abiy L, Dickey R, Lopez JV, Rein KS. Polyketide synthase genes from marine dinoflagellates. Mar Biotechnol 5: 1-12 (2003)

52. Snyder RV, Guerrero MA, Sinigalliano CD, Winshell J, Perez R, Lopez JV, Rein KS. Localization of polyketide synthase encoding genes to the toxic dinoflagellate Karenia brevis. Phytochemistry 66: 1767-1780 (2005)

53. Kubota T, Inuma Y, Kobayashi J. Cloning of polyketide synthase genes from amphidinolide-producing dinoflagellate Amphidinium sp. Biol Pharm Bull 29: 1314-1318 (2006) 